\title{
Religiousness, social support and the use of antidepressants among the elderly: a population-based study
}

\author{
Religiosidade, suporte social e uso de antidepressivos entre idosos \\ residentes em comunidade: um estudo de base populacional
}

\author{
Adriano Roberto Tarifa Vicente ${ }^{1}$ \\ Érico Castro-Costa ${ }^{1}$ \\ Josélia de Oliveira Araújo Firmo ${ }^{1}$ \\ Maria Fernanda Lima-Costa ${ }^{1}$ \\ Antônio Ignácio de Loyola Filho ${ }^{1}$
}

${ }^{1}$ Núcleo de Estudos em Saúde Pública e Envelhecimento, Centro de Pesquisas René Rachou, Fiocruz. Av. Augusto de Lima 1715, Barro Preto. 30190-002 Belo Horizonte MG Brasil.

aloy@cpqrr.fiocruz.br

\begin{abstract}
The purpose of the study was to investigate whether religiousness and social support were associated with the use of antidepressants among community-dwelling elders. The research involved 1,606 older adults who make up the cohort of Bambui Project, a study on ageing and health. The dependent variable was the use of antidepressants in the last 90 days, and the exposures of interest were social support and religiousness. Logistic regression was used to test the associations and to estimate crude and adjusted Odds Ratio and their 95\% confidence intervals. The chances of use of antidepressants were significantly lower among older people with higher level of religiosity $(O R=0.45 ; 95 \%$ CI: 0.29 to 0.70), but none of the descriptors social support was associated with the event. In this population, it is possible that religion occupies a prominent role in the arsenal of health problems coping strategies, especially mental. Health professionals attending this particular segment of the population (elderly people with depressive disorders) should consider religiousness of patients when the proposed guidelines and treatment in coping with their mental suffering.
\end{abstract}

Key words Religiousness, Antidepressants, Social support, Elderly, Medication use
Resumo O propósito do estudo foi investigar se a religiosidade e o suporte social estariam associados ao uso de antidepressivos entre idosos residentes em comunidade. A investigação envolveu 1.606 integrantes da coorte idosa do Projeto Bambuí, um estudo longitudinal sobre envelhecimento e saúde. A variável dependente foi o uso de antidepressivos nos últimos 90 dias, e as exposições de interesse foram suporte social e religiosidade. As hipóteses de associação foram testadas por meio de regressão logística multivariada, que incluiu características sociodemográficas, condições de saúde e uso de serviços de saúde como potenciais fatores de confusão. As chances de utilização de antidepressivos foram significativamente menores entre os idosos com nivel mais elevado de religiosidade (OR =0,45; IC95\%: 0,29-0,7), mas nenhum dos descritores de suporte social mostrou-se associado ao evento. É possível que, nessa população, a religiosidade ocupe um lugar de destaque no arsenal de estratégias de enfrentamento de problemas de saúde, especialmente os mentais. Profissionais de saúde que atendem este segmento específico da população (idosos com transtornos depressivos) devem considerar a religiosidade dos pacientes quando das orientações e tratamento propostos no enfrentamento do seu sofrimento mental.

Palavras-chave Religiosidade, Antidepressivos, Suporte social, Idosos, Uso de medicamentos 


\section{Introduction}

In recent decades, the possible relationships between social support, religiousness and depression have earned the attention of the scientific community with evidence that in both respects, the effect is beneficial, especially among the elderly ${ }^{1-4}$. Social support encourages adherence to programs aimed at promoting health and enhances social interaction ${ }^{5}$. Religiousness already provides engaging in behaviors beneficial to health, from notions of purity of body, mind and spirit (ideas spread by different beliefs). It also stimulates physiological responses through neurotransmitters that enable relaxation in stressful situations and enhances the positive effects of social support on health ${ }^{6}$. Also, religious coping uses cognitive and behavioral strategies for coping with stressful situations, potentially harmful to health in general or mental health ${ }^{7-9}$.

Antidepressants (ADs) are the standardized pharmacological class for treating depression and its use has recently increased ${ }^{10,11}$. Among the elderly, the use of ADs has been frequently associated with females and negative self-assessment of health ${ }^{12,13}$, a history of depression ${ }^{12}$ and more frequent visits to the doctor ${ }^{13}$. However, there is a little information on how the social support and religiousness relate to antidepressants use. Thielen et al. ${ }^{14}$ demonstrated in a longitudinal study among Danish employees that low social support was predictive of incident use of antidepressants in men.

In Brazil, most pharmacoepidemiological studies on factors associated with the use of antidepressants have been conducted among adults ${ }^{15-17}$. To date, few studies ${ }^{18,19}$ has looked at the elderly, finding similar results to previous ones in adults. Among Brazilian investigations, only the study by Garcias et al. ${ }^{17}$ addressed the association between religiousness and the use of antidepressants, showing no significant relationship. So it can be seen that, until today, there is a lack of pharmacoepidemiological studies concerned with investigating whether social support and religiousness could influence the use of antidepressants among the elderly.

Based on this, the present study investigated whether religiousness and social support were associated with the use of antidepressants among the elderly living in the community.

\section{Material and methods}

\section{Study area and population}

In this investigation, baseline data from the Bambuí Cohort Study of Aging, which started in 1997, was used. The Bambuí project is a longitudinal study on aging and health, developed in the city of the same name $(\sim 15,000$ inhabitants $)$ located in the southwest of the state of Minas Gerais, Brazil. At that time, life expectancy at birth was 70.2 years and cerebrovascular accident (CVA), Chagas' disease and ischemic heart disease were the main causes of death among the elderly ${ }^{20}$. The eligible population for the study (residents who were 60 years old or over) was identified from the census of 1 January 1997; of 1,742 residents, 1,606 (92.2\%) constituted the baseline of this cohort and were selected for this study.

\section{Study variables and assessment procedures}

The dependent variable was the use of antidepressants, informed by the participants and checked using both the packaging and the doctor's prescription. Participants were asked if they had used any medication in the last 90 days, and if so, they were asked the name of the drug and how long they used it for. The mentioned drugs were identified, broken down into their active ingredients, and subsequently classified according to the Anatomical Therapeutic Chemical Index (ATC Index) (World Health Organization Collaborating Centre for Drug Statistics Methodology ATC/ DDD Index 2013. Available at www.whocc.no/ atc_ddd_index). This coding system classifies the drug according to the anatomical site on which it operates, its therapeutic action and its pharmacological and chemical properties. All drugs identified by the ATC Index with the N06A code were considered to be antidepressants.

The variables of interest were selected measures of social support and religiousness. The social support variables included the degree of satisfaction in personal relationships (satisfied; indifferent, dissatisfied), having friends who they visit or who visit them (yes, no), taking part in community associations (yes, no), receiving help (financial, housing, company) from their family (yes, no). Regarding the help they received, a positive response to at least one type of help was considered to be receiving help. The weekly 
church attendance (less than once a week; at least once a week) was used to measure religiousness; people that respond "at least once a week" were classified as having a high level of religiousness.

Sociodemographic characteristics and measures of health condition and use of health services previously reported to be associated with the use of antidepressants ${ }^{18}$ were included in the study as potential confounders. Sociodemographic characteristics included gender, age (60$69,70-79$ and 80 or more years) and marital status (married/common-law marriage, widowed, single/divorced). Measures of health condition were cognitive functioning, depressive symptoms and self-rated health (very good/good; reasonable; bad). Cognitive functioning was assessed by the Mini-Mental State Examination (MMSE), defining cognitive impairment by scores below $22^{21}$. Depressive symptoms were evaluated by the 12-item General Health Questionnaire (GHQ12 ), using the cut-off point $\geq 5$, that presented the best trade-off between sensitivity and specificity in this population ${ }^{22}$. The use of health care services were evaluated by the number of visits to the doctor in the last 12 months and if the elderly have a covered health plan (no/yes).

The data collection was carried out using a standardized questionnaire, applied by a team of interviewers, resident in the community, with 11 or more years schooling completed and duly trained by the researchers. The Bambuí Cohort Study of Aging was approved by the Ethics Committee of the Oswaldo Cruz Foundation. All participants were informed about the objectives and procedures of the project and gave informed written consent.

\section{Data analysis}

The Pearson's chi-squared test was used to compare the antidepressant users with non-users, relative to social support and religiousness, as well as sociodemographic characteristics, health status and use of health services. The logistic regression model was used to test the association between the use of antidepressants and the variables of interest (social support descriptors and religiousness) in univariate and multivariate analyses. This model allows us to estimate the odds ratios (OR), crude and adjusted, and their 95\% confidence intervals. Among potential confounders, only age was not included in the multivariate analysis ( $p>0.20$ in univariate analysis). The adequacy of the model was verified by the Hosmer-Lemenshow test and the presence of multicollinearity was tested through variance inflator factors. The significance level to consider a variable independently associated with the use of antidepressants was 5\% $(\mathrm{p}<0.05)$. The Stata statistical software, version 13 (Stata Corporation, College Station, USA) was used to analyze the data.

\section{Results}

Among the 1,606 participants, the majority were female $(60.1 \%)$ and were between 60 and 69 years $(58.1 \%)$; roughly half $(48.9 \%)$ were married or living with a partner. In relation to health, $19.5 \%$ had cognitive dysfunction, $38.5 \%$ presented depressive symptoms and 20.2\% rated their own health as poor or very poor; on average, they consulted a doctor $3.4(\mathrm{SD}=4.9)$ times in the last 12 months, and about two in ten (19.3\%) were covered by health insurance. As for the characteristics of social support, most declared themselves satisfied with their personal relationships $(88.0 \%)$, visiting or receiving visits from friends $(87.6 \%)$, receiving some kind of family help $(63.6 \%)$ and many did not participate in any community associations (83.2\%). In terms of religiousness, the weekly attendance at religious services was $40.7 \%$.

The results of univariate analyses of social support and religiousness are shown in Table 1. The chances of use of antidepressants were higher among those elderly with poor social support only when it comes to the degree of satisfaction with the social relationships, but it was not significant at $\mathrm{p}<0.05$. As for religiousness, the chances of using antidepressants was lower for the old people with a high level of religiousness and this association was significant ( $\mathrm{p}=0.008$ ).

Regarding the sociodemographic characteristics, health status and use of health services included in the study, only age and marital status were not associated with the use of antidepressants ( $\mathrm{p}=0.889$ and $\mathrm{p}=0.122$, respectively). Positive and significant associations were observed for females, bad self-rated health, depressive symptoms, health plan coverage and the number of medical visits, while cognitive impairment presented a negative association with the use of antidepressants $(\mathrm{p}<0.05)$ (Table 2$)$.

Table 3 shows the results of the multivariate analysis for the association of social support and religiousness together and the use of antidepressants, adjusted for each other and for the other variables included in the study (sociodemo- 
Table 1. Results of the univariate analysis of the association between religiousness and social support and the use of antidepressants; Bambuí, 1997.

\begin{tabular}{|c|c|c|c|}
\hline \multirow[b]{2}{*}{ Characteristics } & \multicolumn{2}{|c|}{ Use of Antidepressants } & \multirow[b]{2}{*}{$\begin{array}{c}\text { Odds Ratio }(95 \% \\
\text { CI) }\end{array}$} \\
\hline & $\begin{array}{c}\text { No } \\
(\mathrm{n}=1,471) \\
\%\end{array}$ & $\begin{array}{c}\text { Yes } \\
(\mathbf{n}=135) \\
\%\end{array}$ & \\
\hline \multicolumn{4}{|l|}{ Social support } \\
\hline \multicolumn{4}{|c|}{ Degree of satisfaction with social relationships } \\
\hline Satisfied & 92.1 & 7.9 & 1.00 \\
\hline Indifferent & 77.6 & 12.4 & $1.64(0.87-3.09)$ \\
\hline \multirow[t]{2}{*}{ Dissatisfied } & 89.5 & 10.5 & $1.38(0.70-2.74)$ \\
\hline & \multicolumn{2}{|c|}{$(\mathrm{p}<0.222)$} & \\
\hline \multicolumn{4}{|c|}{ Has friends who visit them or who they visit } \\
\hline Yes & 91.2 & 8.8 & 1.00 \\
\hline \multirow[t]{2}{*}{ No } & 93.4 & 6.6 & $0.73(0.41-1.33)$ \\
\hline & $(\mathrm{p}$ & & \\
\hline \multicolumn{4}{|c|}{ Participates in community associations } \\
\hline No & 91.7 & 8.3 & 1.00 \\
\hline \multirow[t]{2}{*}{ Yes } & 91.4 & 8.6 & $1.04(0.65-1.67)$ \\
\hline & $(\mathrm{p}$ & & \\
\hline \multicolumn{4}{|l|}{ Receives help from the family } \\
\hline Yes & 91.6 & 8.4 & 1.00 \\
\hline \multirow[t]{2}{*}{ No } & 91.6 & 8.4 & $1.01(0.70-1.45)$ \\
\hline & $(\mathrm{p}$ & & \\
\hline \multicolumn{4}{|c|}{ Religiousness } \\
\hline \multicolumn{4}{|c|}{ Weekly frequency to religious services } \\
\hline No & 90.0 & 10.0 & 1.00 \\
\hline \multirow[t]{2}{*}{ Yes } & 93.8 & 6.2 & $0.60(0.41-0.87)$ \\
\hline & $(\mathrm{p}$ & & \\
\hline
\end{tabular}

$P$ value obtained using the Pearson chi-squared test. Odds Ratios and their 95\% CI (Confidence Interval 95\%) obtained using logistic regression.

graphic, health and use of health services). After being adjusted, religiousness was significantly associated with the use of antidepressants $(\mathrm{OR}=$ 0.45; 95\%CI: 0.29 to 0.70 ), but the same was not seen for any of social support measures. Among the variables used for the purpose of adjustment, remained significantly associated in the multivariate model gender, self-rated health, cognitive impairment, number of medical visits and health insurance cover.

\section{Discussion}

In this population, the use of antidepressants was associated to religiousness, with the elderly who attended religious services most frequently showing significantly less likelihood of using the antidepressants. This association held up even with a set of relevant variables in explaining the use of drugs in general and in the specific use of antidepressants. The same was not detected in relation to the social support measures, in that the use of antidepressants in the elderly did not vary significantly with different levels of social support. To the best of our knowledge, this is the first study that investigated the association between religiousness and social support an the use of antidepressants among older adults.

The association between religiousness and depressive symptoms has been investigated in different populations, and in most of them, the most intense religiousness is associated with lower frequency of depressive symptoms ${ }^{2,4,7,9,23,24}$ decrease of the symptoms ${ }^{25}$ or remission ${ }^{1,26}$. So far, only one epidemiological population-based 
Table 2. Results of the univariate analysis of sociodemographic characteristics, health status and use of health services associated with the use of antidepressants; Bambuí, 1997.

\begin{tabular}{|c|c|c|c|}
\hline \multirow[b]{2}{*}{ Characteristics } & \multicolumn{2}{|c|}{ Use of antidepressants } & \multirow[b]{2}{*}{ Odds Ratio (95\% CI) } \\
\hline & $\begin{array}{c}\text { No } \\
(\mathrm{n}=1,471) \\
\% \text { or mean }\end{array}$ & $\begin{array}{c}\text { Yes } \\
(n=135) \\
\% \text { or mean }\end{array}$ & \\
\hline \multicolumn{4}{|l|}{ Gender } \\
\hline Male & 18.5 & 3.9 & 1.00 \\
\hline \multirow[t]{2}{*}{ Female } & 81.5 & 11.4 & $3.17(2.03-4.95)$ \\
\hline & \multicolumn{2}{|c|}{$(\mathrm{p}<0.001)$} & \\
\hline \multicolumn{4}{|l|}{ Age } \\
\hline 60-69 years old & 91.3 & 8.7 & 1.00 \\
\hline 70-79 years old & 92.1 & 7.9 & $0.91(0.61-1.35)$ \\
\hline \multirow{2}{*}{$\geq 80$ years old } & 91.8 & 8.2 & $0.95(0.53-1.68)$ \\
\hline & \multicolumn{2}{|c|}{$(\mathrm{p}=0.889)$} & \\
\hline \multicolumn{4}{|l|}{ Marital status } \\
\hline Married/common-law marriage & 91.2 & 8.8 & 1.00 \\
\hline Widow(er) & 90.7 & 9.3 & $1.07(0.73-1.55)$ \\
\hline \multirow[t]{2}{*}{ Single/Separated } & 94.8 & 5.2 & $0.56(0.31-1.04)$ \\
\hline & \multicolumn{2}{|c|}{$(\mathrm{p}=0.122)$} & \\
\hline \multicolumn{4}{|l|}{ Cognitive dysfunction } \\
\hline No & 90.5 & 9.5 & 1.00 \\
\hline \multirow[t]{2}{*}{ Yes } & 96.3 & 3.7 & $0.38(0.20-0.71)$ \\
\hline & \multicolumn{2}{|c|}{$(\mathrm{p}=0.002)$} & \\
\hline \multicolumn{4}{|l|}{ Depressive symptoms } \\
\hline No & 93.3 & 6.7 & 1.00 \\
\hline \multirow[t]{2}{*}{ Yes } & 89.3 & 10.7 & $1.67(1.15-2.41)$ \\
\hline & \multicolumn{2}{|c|}{$(\mathrm{p}=0.006)$} & \\
\hline \multicolumn{4}{|l|}{ Self-rated health status } \\
\hline Very good/good & 94.2 & 5.8 & 1.00 \\
\hline Reasonable & 91.1 & 8.9 & $1.59(1.03-2.46)$ \\
\hline \multirow[t]{2}{*}{ Poor/Very Poor } & 88.3 & 11.7 & $2.16(1.32-3.53)$ \\
\hline & \multicolumn{2}{|c|}{$(\mathrm{p}=0.008)$} & \\
\hline \multicolumn{4}{|l|}{ Health Insurance Cover } \\
\hline No & 92.4 & 7.6 & 1.00 \\
\hline \multirow[t]{2}{*}{ Yes } & 88.4 & 11.6 & $1.59(1.06-2.38)$ \\
\hline & \multicolumn{2}{|c|}{$(\mathrm{p}=0.023)$} & \\
\hline \multirow[t]{2}{*}{$\begin{array}{l}\text { Number of doctor's appointments in the last } \\
12 \text { months }\end{array}$} & 3.2 & 5.5 & $1.06(1.03-1.09)$ \\
\hline & \multicolumn{2}{|c|}{$(\mathrm{p}<0.001)$} & \\
\hline
\end{tabular}

$P$ value obtained by Pearson's chi-square test for proportions and the Student $t$ test for means. Odds Ratios and their 95\% CI (Confidence Interval 95\%) obtained using logistic regression.

study has tested hypotheses of the association between religiousness and the use of antidepressants, and it was done among adults ${ }^{17}$.

The ways in which religiousness and health relate to each other involve behavioral, social, psychological and even physiological aspects ${ }^{6}$. In a wider perspective, religious practices are supported in a symbolic universe that gives a spiritual character to events such as illness and death by in- creasing the individual capacity of understanding and acceptance of these adverse health events ${ }^{6,9}$. In the field of relations between religiousness and health, religious coping has been highlighted as an important predictor of health outcomes ${ }^{8,27}$. Attendance at religious services favors the adoption of religious coping ${ }^{8}$, starting with the social support received by the individual through contact and interaction with other church members 
Table 3. Results of the multivariate analysis of the association between social support and religiousness and the use of antidepressants; Bambuí, 1997.

\section{Variables}

Odds Ratio

(95\% CI)

Satisfaction with social relationships
Satisfied
Indifferent
Dissatisfied

Has friends who visit them or who they visit

Yes

No

Participates in community associations

No

Yes

Receives family help

Yes

No

Weekly frequency to religious services

No

Yes

Gender

Male

Female

Marital status

Married/common-law marriage

Widow(er)

Single/Separated

Cognitive dysfunction

No

Yes

Depressive symptoms

No

Yes

Self-rated health status

Very good/good

Reasonable

Poor/very poor

Number of doctor's appointments in the last 12 months

Health Insurance Cover

No

Yes Odds Ratios and their 95\% CI (Confidence Interval 95\%) obtained using logistic regression, adjusted for all the variables of the
table. $P$ value obtained using the Wald test.

during the services ${ }^{28}$. The religious coping may be an adjunctive therapy in the approach to health problems ${ }^{29}$. It is suspected that for the elderly population of Bambuí, religiousness may represent a religious coping strategy to deal with depressive symptoms. This idea is reinforced by the fact that this association has been observed among elderly people with depressive symptoms, unlike that which occurred among those without them, in which the association was not significant (results not shown). In Bambuí, a recent ethnographic study showed that, for the elderly, religious coping is important in confronting disability, leading to the acceptance of this condition as something inherent to the aging process and allowing for less distress when living with the condition, to estab- 
lish a spiritual link between two situations: one real and hard to bear (i.e. disability), and the other utopian and inspired (i.e. autonomy ${ }^{30}$.

Religiousness and social support are strongly interconnected ${ }^{4}$, since attendance at religious services promotes social interaction, decreasing isolation and loneliness, that are consequence or strengthen depressive symptoms ${ }^{1,4,28}$. On the other hand, social support has been associated with the use of antidepressants ${ }^{14}$ and adherence to drug treatment of depression ${ }^{31}$. Therefore, social support variables were included aimed at, not only the investigation of a specific association, but also to see whether the social support could act as a mediator element or represented a confounding factor in a possible association between religiousness and use of antidepressant $t^{4,24}$. In this research, the social support measures included mean opportunities for integration and social interaction, and assess the degree of satisfaction with social relations. However, in Bambuí, as in other Brazilian elderly study population ${ }^{3}$, social support was not important in explaining the use of antidepressants, nor was the association between religiousness and use of antidepressants mediated or confused by it.

An important limitation of this study is its cross-sectional design, which prevents the distinction in time between the studied exposures of interest (in this case, religiousness and social support) and the event (the use of antidepressants). Several authors warn of the bidirectional nature of the relationship between religiousness and health events ${ }^{26-27,32}$, making it difficult to understand if the intense religiousness is a result of good health or if this has a positive influence, especially if we consider the religiousness in its public expression, as is the case here. Thus, one cannot define clearly whether antidepressant use is influenced by or influences religiousness. Another limitation concerns the absence of measures of access to medication or other treatment, or even measures specific to religious coping. It is possible that the adoption of a different strategy other than pharmacology in dealing with health problems results from inaccessibility to the medicine, or that the association between religiousness and the use of antidepressants could be confused by the adoption of psychotherapy. The presence of such variables in the model would certainly provide elements for a more precise analysis of the data and a less speculative interpretation of the results.

However, the study does have important characteristics such as its strength due to its population-based design, allowing for generalization of the results for this target population, and the methodological care taken in collecting the data (standardized tools and the intensive training of the interviewers). Moreover, this study could provide groundwork and be an important stimulus so that Brazilian scientific production starts to include, more and more often, religiousness as a field of study and, also, considers the use of different methodologies in the production of knowledge on this matter.

Summarizing, the results of this study indicate the possibility that, for the elderly, religiousness occupies a prominent place in the arsenal of strategies for coping with health problems, especially mental health problems. As a result, health professionals caring this specific segment of the population (elderly people with depressive symptoms) should consider the religiousness of patients with regard to proposed guidelines and treatment in addressing their mental suffering.

\section{Collaborators}

ART Vicente and AI Loyola-Filho contributed toward the conception and design, data analysis, interpretation of data, and writing of the manuscript. E Castro-Costa contributed to interpretation of data and writing of the manuscript. JOA Firmo and MF Lima-Costa contributed to the data collection and critical revision of the manuscript. 


\section{References}

1. Ronneberg CR, Miller EA, Dugan E, Porell F. The Protective Effects of Religiosity on Depression: A 2-Year Prospective Study. Gerontologist 2016; 56(3):421-431.

2. Sun F, Park NS, Roff LL, Klemmack DL, Parker M, Koenig HG, Sawyer P, Allman RM. Predicting the trajectories of depressive symptoms among southern community-dwelling older adults: The role of religiosity. Aging Ment Health 2012; 16(2):189-198.

3. Correa AAM, Moreira-Almeida A, Menezes PR, Vallada H, Scazufca M. Investigating the role played by social support in the association between religiosity and mental health in low income older adults: results from the São Paulo Ageing \& Health Study (SPAH). Rev Bras Psiquiatr 2011; 33(2):157-164.

4. Koenig HG, Hays JC, George LK, Blazer DG, Larson DB, Landerman LR. Modeling the cross-sectional relationships between religion, physical health, social support, and depressive symptoms. Am J Geriatr Psychiatry 1997; 5(2):131-144.

5. Moreira-Almeida A, Lotufo Neto F, Koenig HG. Religiousness and mental health: a review. Rev Bras Psiquiatr 2006; 28(3):242-250.

6. Idler EL, Musick MA, Ellison CG, Geroge LK, Krause N, Ory MG, Pargament KI, Powell LH, Underwwod LG, Williams DR. Measuring Multiple Dimensions of Religion and Spirituality for Health Research. Res Aging 2003; 25(4):327-365.

7. Lucchetti G, Lucchetti ALG, Peres MFP, Moreira-Almeida A, Koenig HG. Religiousness, Health, and Depression in Older Adults from a Brazilian Military Setting. ISRN Psychiatry 2012; 2012:94074.

8. Panzini RG, Bandeira DR. Coping (enfrentamento) religioso/espiritual. Rev Psiq Clin 2007; 34 (1 Supl.):126135.

9. Bosworth HB, Park KS, McQuoid DR, Hays JC, Steffens DC. The impact of religious practice and religious coping on geriatric depression. Int J Geriatr Psychiatry 2003; 18(10):905-914.

10. Lockhart P, Guthrie B. Trends in primary care antidepressant prescribing 1995-2007: a longitudinal population database analysis. $\mathrm{Br} J$ Gen Pract 2011; 61(590):e565-e572.

11. Marcus SC, Olfson M. National Trends in the Treatment for Depression From 1998 to 2007. Arch Gen Psychiatry 2010; 67(12):1265-1273.

12. Soudry A, Dufouil C, Ritchie K, Dartigues JF, Tzourio C, Alpérovitch A. Factors associated with antidepressant use in depressed and non-depressed community-dwelling elderly: the three-city study. Int $J$ Geriatr Psychiatry 2008; 23(3):324-330.

13. Brown SL, Salive ME, Guralnik JM, Pahor M, Chapman DP, Blazer D. Antidepressant use in the elderly: association with demographic characteristics, health-related factors, and health care. J Clin Epidemiol 1995; 48(3):445-453.

14. Thielen K, Nygaard E, Rugulies R, Diderichsen F. Job stress and the use of antidepressant medicine: a 3.5year follow-up study among Danish employees. Occup Environ Med 2011; 68(3):205-210.
15. Blay SL, Fillenbaum GG, Pitta JC, Peluso ET. Factors associated with antidepressant, anxiolytic, and other psychotropic medication use to treat psychiatric symptoms in the city of São Paulo, Brazil. Int Clin Psychopharmacol 2014; 29(3):157-165.

16. Brunoni AR, Nunes MA, Figueiredo R, Barreto SM, da Fonseca Mde J, Lotufo PA, Benseñor IM. Patterns of benzodiazepine and antidepressant use among middle-aged adults. The Brazilian longitudinal study of adult health (ELSA-Brasil). J Affect Disord 2013; 151(1):71-77.

17. Garcias CMM, Pinheiro RT, Garcias GL, Horta BL, Brum CB. Prevalência e fatores associados ao uso de antidepressivos em adultos de área urbana de Pelotas, Rio Grande do Sul, Brasil, em 2006. Cad Saude Publica 2008; 24(7):1565-1571.

18. Vicente ART, Castro-Costa E, Diniz BS, Firmo JOA, Lima-Costa MF, Loyola Filho AI. Antidepressant use and associated factors among the elderly: The Bambuí Project. Cien Saude Colet 2015; 20(12):3797-3804.

19. Loyola Filho AI, Castro-Costa E, Firmo JL, Peixoto SR. Trends in the use of antidepressants among older adults: Bambuí- Project. Rev Saude Publica 2014; 48(6):857-865.

20. Lima-Costa MF, Firmo JOA, Uchoa E. Cohort Profile: The Bambuí (Brazil) Cohort Study of Ageing. Int J Epidemiol 2011; 40(4):862-867.

21. Castro-Costa E, Fuzikawa C, Uchoa E, Firmo JOA, Lima-Costa MF. Norms for the Mini-Mental State Examination - Adjustment of the cut-off point in population-based studies (evidences from the Bambuí health aging study). Arq Neuropsiquiatr 2008; 66(3A):524-528.

22. Castro-Costa E, Lima-Costa MF, Carvalhais S, Firmo JOA, Uchoa E. Factors associated with depressive symptoms measured by the 12-item General Health Questionnaire in Community-Dwelling Older Adults (The Bambuí Health Aging Study). Rev Bras Psiquiatr 2008; 30(2):104-109.

23. Hayward RD, Owen AD, Koenig HG, Steffens DC, Payne ME. Religion and the presence and severity of depression in older adults. Am J Geriatr Psychiatry 2012; 20(2):188-192.

24. Baetz M, Griffin R, Bowen R, Koenig HG, Marcoux E. The association between spiritual and religious involvement and depressive symptoms in a Canadian population. J Nerv Ment Dis 2004; 192(12):818-822.

25. Zou J, Huang Y, Maldonado L, Kasen S, Cohen P, Chen $\mathrm{H}$. The efficacy of religious service attendance in reducing depressive symptoms. Soc Psychiatry Psychiatr Epidemiol 2014; 49(6):911-918.

26. Schettino JR, Olmos NT, Myers HF, Joseph NT, Poland RE, Lesser IM. Religiosity and treatment response to antidepressant medication: A prospective multi-site clinical trial. Ment Health Relig Cult 2011; 14(8):805818.

27. Brewer G, Robinson S, Sumra A, Tatsi E, Gire N. The Influence of Religious Coping and Religious Social Support on Health Behaviour, Health Status and Health Attitudes in a British Christian Sample. J Relig Health 2015; 54(6):2225-2234. 
28. Krause N. Church-based social support and health in old age: exploring variations by race. J Gerontol B Psychol Sci Soc Sci 2002; 57(6):S332-S347.

29. Banerjee AT, Strachan PH, Boyle MH, Anand SS, Oremus M. Attending religious services and its relationship with coronary heart disease and related risk factors in older adults: a qualitative study of church pastors' and parishioners' perspectives. J Relig Health 2014; 53(6):1770-1785.

30. Santos WJ, Giacomin KC, Pereira JK, Firmo JO. Coping with functional disability among the elderly by means of religious beliefs. Cien Saude Colet 2013; 18(8):23192328.

31. Lee MS, Lee HY, Kang SG, Yang J, Ahn H, Rhee M, Ko $\mathrm{YH}$, Joe SH, Jung IK, Kim SH. Variables influencing antidepressant medication adherence for treating outpatients with depressive disorders. J Affect Disord 2010; 123(1-3):216-221.

32. Rasic D, Asbridge M, Kisely S, Langille D. Longitudinal associations of importance of religion and frequency of service attendance with depression risk among adolescents in Nova Scotia. Can J Psychiatry 2013; 58(5):291299.

Artigo apresentado em 07/03/2016

Aprovado em 21/06/2016

Versão final apresentada em 23/06/2016 
